\title{
Entrepreneurship and the Policy Environment
}

\author{
Yannis Georgellis and Howard J. Wall
}

\begin{abstract}
This paper uses a panel approach to examine the effect that the government-policy environment has on the level of entrepreneurship. Specifically, the authors investigate whether marginal income tax rates and bankruptcy exemptions influence rates of entrepreneurship. Whereas previous work in the literature finds that both policies are positively related to entrepreneurship, these results show non-monotonic relationships: a U-shaped relationship between marginal tax rates and entrepreneurship and an S-shaped relationship between bankruptcy exemptions and entrepreneurship.
\end{abstract}

Federal Reserve Bank of St. Louis Review, March/April 2006, 88(2), pp. 95-111.

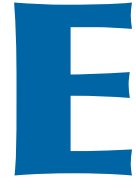

ntrepreneurship is thought to be an important factor in cultivating innovation, employment, and economic growth. Because the benefits flowing from entrepreneurship are not necessarily captured by the entrepreneurs themselves, but can be realized more generally, the case is often made that the level of entrepreneurship is below its social optimum and deserves some attention from policymakers. Despite the recognized importance of entrepreneurship, however, there has been relatively little empirical analysis of the role played by the government-policy environment.

Previous research on self-employment and entrepreneurship has examined the roles of various demographic, human capital, and financial considerations in a person's decision to become an entrepreneur. Typically, studies have indicated the importance of (i) the earnings differential between entrepreneurship and paid employment (Rees and Shah, 1986; Gill, 1988; and Hamilton, 2000); (ii) liquidity constraints (Evans and Jovanovic, 1989; Evans and Leighton, 1989; HoltzEakin, Joulfaian, and Rosen, 1994a,b; and Black and Strahan, 2002); (iii) satisfaction differentials (Taylor, 1996; Blanchflower and Oswald, 1998; and Blanchflower, 2000); (iv) macroeconomic conditions (Taylor, 1996; Parker, 1996; and Cowling and Mitchell, 1997); and (v) intergenerational human capital transfers (Dunn and Holtz-Eakin, 2000; and Hout and Rosen, 2000). ${ }^{1}$

Empirical studies that have considered the effects of the policy environment on entrepreneurship have focused on personal income tax rates, with the expectation that higher tax rates should suppress entrepreneurship. Nearly all studies, however, have found a positive relationship, whether it is between tax rates and aggregate rates of entrepreneurship (Long, 1982a; Evans and Leighton, 1989; Blau, 1987; Parker, 1996; Robson, 1998; and Bruce and Mohsin, 2003) or between tax rates and the likelihood that an individual will be an entrepreneur (Long, 1982b; Schuetze, 2000; and Fan and White, 2003).

The divergence between expectations and results with regard to the effects of the personal

1 Le (1999) provides a fairly comprehensive survey of the empirical literature.

Yannis Georgellis is a senior lecturer in the department of economics and finance at Brunel University, Uxbridge, United Kingdom. Howard J. Wall is an assistant vice president at the Federal Reserve Bank of St. Louis. The authors acknowledge the comments and suggestions of Kate Antonovics, Mark Partridge, Mike Dueker, and seminar participants at the Southern Illinois University at Carbondale and the annual conference of the Western Economic Association International, Seattle, June 29-July 3, 2002. Paige Skiba provided research assistance.

(C) 2006, The Federal Reserve Bank of St. Louis. Articles may be reprinted, reproduced, published, distributed, displayed, and transmitted in their entirety if copyright notice, author name(s), and full citation are included. Abstracts, synopses, and other derivative works may be made only with prior written permission of the Federal Reserve Bank of St. Louis. 
income tax is usually attributed to the perception that, because of the nature of a tax system that relies on self-reporting, being an entrepreneur allows for relatively greater opportunities for tax evasion. ${ }^{2}$ Cullen and Gordon (2002), however, argue that, because entrepreneurs decide whether or not to incorporate their business, and because personal income tax rates are higher than corporate rates, the tax system provides a net subsidy to risk-taking. This net subsidy arises because an entrepreneur facing losses would prefer to face personal income tax rates so that the deduction of the losses against other income would have greater tax-reducing value. All else equal, an increase in personal income tax rates makes this option more valuable, thereby increasing the likelihood that someone would choose to become an entrepreneur.

Other studies have begun to look at the question of taxes and entrepreneurship using morecomplicated indicators of the tax system. Robson and Wren (1999) separate the effects of average and marginal tax rates, suggesting that the former represents the incentive for tax evasion while the latter represents the disincentive. ${ }^{3}$ Bruce (2000) looks at the differential tax treatment of self-employment and wage-and-salary earnings, finding that marginal and average tax rates on self-employment earnings are negatively related to the probability of becoming self-employed. Gentry and Hubbard (2000) find that the more progressive a tax system is, the less likely it is that an individual will enter self-employment. Bruce, Deskins, and Mohsin (2004) look at statelevel differences in a variety of tax policies, including rates of sales taxes and personal and corporate income taxes, along with whether states allow combined reporting and limited liability corporations.

A recently opened line of inquiry into the effects of the policy environment on entrepre-

\footnotetext{
2 Robson and Wren (1999) is an exception that finds a negative relationship between tax rates and entrepreneurship. The authors also have a theoretical model of tax evasion and the entrepreneurial decision.

3 Their theoretical model separates the tax effects into pure marginal and pure average tax changes, roughly analogous to substitution and income effects. Unfortunately, the tax rates they use in their empirical analysis are simply the average and marginal tax rates, each of which has income and substitution effects.
}

neurship has raised the question of whether or not bankruptcy laws affect the number of entrepreneurs (Berkowitz and White, 2004; Fan and White, 2003; and White, 2001). Briefly, U.S. bankruptcy laws allow individuals filing for personal bankruptcy to exempt some of their assets and income from distribution to their creditors. The exemptions, which differ a great deal across states, can include some or all of the value of a person's home (the homestead exemption), pension holdings, and an assortment of other assets. ${ }^{4}$

The direct effect of these exemptions is to provide a sort of wealth insurance in the event that an entrepreneurial venture fails. Thus, through this wealth-insurance effect, higher exemption levels should lead to more entrepreneurs. Less direct than the wealth-insurance effect is a creditaccess effect, which works in the opposite direction. It arises because banks and other credit providers adjust their actions in response to changes in bankruptcy exemptions. As a result, the higher the exemption level, the less credit will be available at a given interest rate. ${ }^{5}$ These two opposing effects of bankruptcy exemptions on entrepreneurship mean that the sign of the total effect is ambiguous in general. However, Fan and White (2003) find that the wealth-insurance effect dominates the credit-access effect for all levels of the exemption. In fact, they find that homeowners in states with an unlimited homestead exemption are 35 percent more likely to be selfemployed than equivalent homeowners in states with low exemption levels.

In an attempt to resolve the discrepancies in estimating the effects of taxes and to enhance the modeling of bankruptcy exemptions, we estimate the effects of government policies on entrepreneurship in a different way. Specifically, following Georgellis and Wall (2000a), we create a state-level panel dataset that pools observations over space and time. ${ }^{6}$ This allows us to look at the effects of

\footnotetext{
4 For detailed discussions of U.S. personal bankruptcy laws and the incentives they create, see White (1998), Fay, Hurst, and White (2002), Gropp, Scholz, and White (1997), and Dye (1986).

5 Berkowitz and White (2004) show how small, unincorporated businesses face lower credit access and higher interest rates in states with higher exemption levels.

${ }^{6}$ See also Wall (2004), Bruce, Deskins, and Mohsin (2004), and Black and Strahan (2002).
} 
changes in policies over time while exploiting the large differences across states in levels of entrepreneurship, bankruptcy exemptions, and tax rates. The advantages of this approach over aggregate time-series studies-which have only one observation per time period-are that we can include a large number of control variables, use more-general specifications of policy variables, and control for trends more effectively. Another advantage, which we outline in greater detail below, is that it allows us to create a continuous variable for the homestead exemption, rather than having to group different exemption levels together into dummy variables, as is necessary when using individual-level panels.

Using the panel approach, we find a U-shaped relationship between marginal tax rates and entrepreneurship. At low tax rates the relationship is negative, and at high rates it is positive. Also, we find an S-shaped relationship between the homestead exemption and entrepreneurship. Specifically, an increase in the homestead exemption from very low or very high levels acts to reduce the number of entrepreneurs, while an increase in the middle range acts to increase the number of entrepreneurs.

\section{SPATIAL AND TEMPORAL TRENDS IN U.S. ENTREPRENEURSHIP}

We define the rate of entrepreneurship as the proportion of the working-age population that is classified as nonfarm proprietors. As with most of the literature, we exclude farm proprietors on the grounds that the decision to become a farm proprietor depends on different factors than the decision to become a nonfarm proprietor; also, farmers operate under their own set of bankruptcy laws.

Proprietors' employment is the number of people who are employed in their own business, regardless of whether that business is incorporated. Various other definitions of entrepreneurship have been used in the literature, such as the nonfarm self-employed, which excludes farmers and the incorporated. ${ }^{7}$ The rate of entrepreneur-

\footnotetext{
7 Bruce and Holtz-Eakin (2001) examine a variety of measures and
} conclude that it makes little difference which is used. ship is usually calculated with the labor force or total employment in the denominator. We prefer to use the working-age population (ages 18-64) because, unlike the size of the labor force or the number employed, it is not likely to move with the number of entrepreneurs as people move between employment states. This distinction also recognizes the fact that entrepreneurs are drawn from the entire working-age population, not just those currently employed or in the labor force.

Figure 1 illustrates the cross-state differences in the levels and growth of entrepreneurship during our sample period, 1991-98. In general, states in the western half of the country had the highest levels of entrepreneurship. The eastern part of the country contained all of the regions with the lowest rates of entrepreneurship: the Great Lakes, the Upper South, and the Deep South. In the East, only New England states were in the top two quartiles of entrepreneurship. As Figure 1B shows, all states saw increases in their rates of entrepreneurship between 1991 and 1998, and there was some convergence. Southern states, New York, and some of the lagging western states had the highest growth in entrepreneurship.

\section{EMPIRICAL MODEL}

Following Georgellis and Wall (2000a), we estimate state rates of entrepreneurship with the following regression equation, using $t$ to denote the time period and $i$ to denote the state:

$$
E_{i t}=\alpha_{i}+\tau_{t}+\boldsymbol{\beta}^{\prime} \mathbf{X}_{\mathrm{it}}+\boldsymbol{\theta}^{\prime} \mathbf{Z}_{\mathbf{i t}}+\boldsymbol{\gamma}^{\prime} \mathbf{G}_{\mathrm{it}}+\varepsilon_{i t} .
$$

In the above expression, $\alpha_{i}$ is a state-specific component that is constant over time and $\tau_{t}$ is a year-specific component that is common to all states. The vectors $\mathbf{Z}_{\text {it }}$ and $\mathbf{X}_{\mathbf{i t}}$ measure, respectively, lagged business conditions and lagged average demographic characteristics in state $i$ in year $t$. Government policy variables are included in the vector $\mathbf{G}_{\mathbf{i t}}$, and $\varepsilon_{i t}$ is the error term.

The demographic variables included in $\mathbf{X}_{\text {it }}$ capture the spatial and temporal differences in age, gender, and racial compositions of state employment. As outlined in Georgellis and Wall (2000b), rates of self-employment differ a great deal across these categories. We therefore include 
Figure 1A

Average Rates of Entrepreneurship, 1991-98

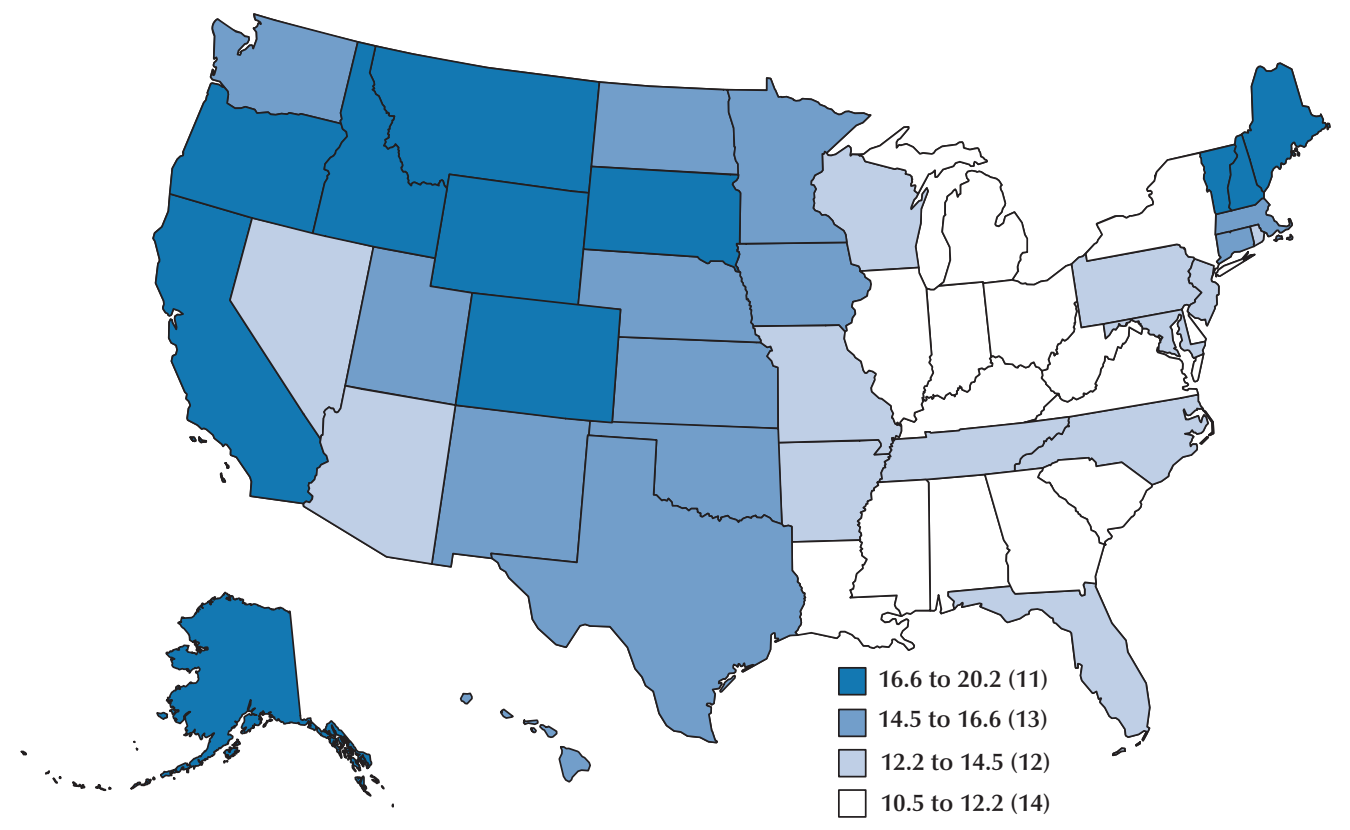

\section{Figure 1B}

\section{Changes in Rates of Entrepreneurship, 1991-98}

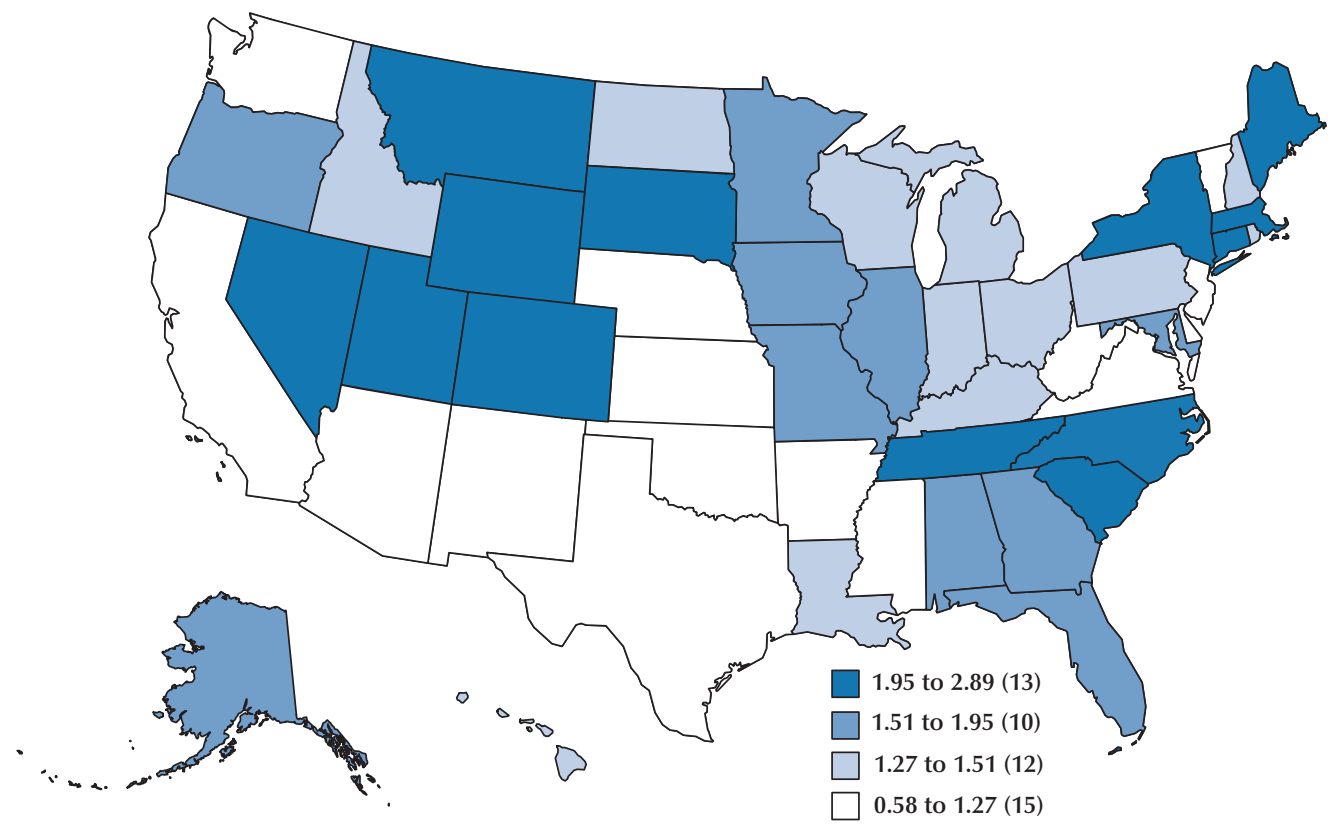


age variables that measure differences in employment shares of broad age categories. Also, because men are nearly twice as likely as women to be self-employed, we include the female share of a state's employment. Finally, $\mathbf{X}_{\text {it }}$ includes the black, Native American, Asian and Pacific Islander, and Hispanic employment shares. Large variations in self-employment across these groups might explain state-level differences in entrepreneurship. For example, the self-employment rate for blacks is only about one-third of that for whites and Asians.

Here and in the previous section we discuss these variables in terms of the supply of potential entrepreneurs. However, one should be careful about the interpretation of the estimated coefficients because these demographic groups might also differ in their demand for the products that are more likely to be produced by entrepreneurs. For example, as Georgellis and Wall (2000b) report, over 10 percent of self-employed women in 1997 were in the child-care business, while virtually no men were. This indicates that a state with a higher-than-average female employment share might have a higher-than-average supply of child-care providers. On the other hand, such a state also has a higher-than-average number of women demanding child-care services.

The vector of business conditions, $\mathbf{Z}_{\mathrm{it}}$, includes measures of a state's economy that affect the profitability of entrepreneurship. These include the state's unemployment rate, per capita real income, per capita real wealth (as proxied by dividends, interest, and rent), relative proprietor's wage, and industry employment shares. As with our demographic variables, the interpretation of the roles of these variables is not entirely clear because each can simultaneously indicate the demand for entrepreneurs' services and the supply of entrepreneurs. For example, while we include the unemployment rate as a measure of the health of a state's economy, Parker (1996), among others, includes it as an indicator of the number of people with limited opportunities for wage-and-salary employment who might be pushed into selfemployment.

As Georgellis and Wall (2000a) demonstrate, the specification of our control variables-the elements of $\mathbf{X}_{\mathrm{it}}$ and $\mathbf{Z}_{\mathrm{it}}$-is potentially important. The authors show, for example, that the relationship between the rates of self-employment and unemployment in Britain is hill-shaped. Indeed, the best fit in the present context would allow for nonlinear relationships. Nonetheless, our present purpose is to estimate the effects of taxes and the homestead exemption, and a simple linear specification for the control variables makes little difference in this regard. Therefore, for parsimony, we use a linear specification for these control variables.

Presently, the variables of most interest are those measuring marginal tax rates and the homestead exemption. For the former, we use the maximum marginal tax rates (state plus federal) as generated by the National Bureau of Economic Research's TAXSIM model (see Table 1 for the state maximum marginal tax rates in 1990 and 1997, the first and last years of data used in our study). Of the tax rate measures used in the literature, this one best fits our needs. For one, it is the measure used in the paper most comparable to ours-Fan and White (2003). But, more importantly, it is exogenous, unlike the average marginal tax rate also generated by TAXSIM. Although very few people will actually face the maximum marginal tax rate, there should be a very strong correlation between the marginal tax rates that the average person faces and the maximum rate.

We constructed our homestead exemption variable to take into account several state-level differences in bankruptcy law and to provide a measure of the percentage of the value of the average person's home that is exempt from bankruptcy proceedings. First, as noted above and as summarized by Table 1, there are large differences in the exemption level across states: In 1997, five states did not allow any homestead exemption, whereas seven had an unlimited exemption. Also, some states allow for the federal exemption to be substituted at the filer's discretion, and some states allow married filers to double the exemption level. We also take into account differences in the average house prices and the likelihood that a filer owns rather than rents.

Our homestead exemption variable starts by taking the state exemption level or, if the state 
Table 1

State Homestead Exemptions and Maximum Marginal Tax Rates

\begin{tabular}{|c|c|c|c|c|}
\hline \multirow[b]{2}{*}{ State } & \multicolumn{2}{|c|}{ Maximum marginal tax rates $(\%)$} & \multicolumn{2}{|c|}{ Homestead exemptions (\$) } \\
\hline & 1990 & 1997 & 1990 & 1997 \\
\hline Alabama & 3.65 & 3.12 & 5,000 & 5,000 \\
\hline Alaska & 0 & 0 & 54,000 & 54,000 \\
\hline Arizona & 6.51 & 4.8 & 100,000 & 100,000 \\
\hline Arkansas & 7 & 7 & No limit & No limit \\
\hline California & 9.3 & 9.78 & 7,500 & 15,000 \\
\hline Colorado & 4.76 & 5.36 & 20,000 & 30,000 \\
\hline Connecticut & 0 & 4.5 & 0 & 75,000 \\
\hline Delaware & 7.7 & 6.9 & 0 & 0 \\
\hline Florida & 0 & 0 & No limit & No limit \\
\hline Georgia & 5.66 & 5.83 & 5,000 & 5,000 \\
\hline Hawaii & 9 & 9 & 30,000 & 30,000 \\
\hline Idaho & 8.2 & 8.2 & 30,000 & 50,000 \\
\hline Illinois & 3 & 3 & 7,500 & 7,500 \\
\hline Indiana & 3.4 & 3.4 & 7,500 & 7,500 \\
\hline lowa & 7.39 & 6.36 & No limit & No limit \\
\hline Kansas & 5.15 & 6.45 & No limit & No limit \\
\hline Kentucky & 4.39 & 6 & 5,000 & 5,000 \\
\hline Louisiana & 4.14 & 3.75 & 15,000 & 15,000 \\
\hline Maine & 8.5 & 8.5 & 7,500 & 12,500 \\
\hline Maryland & 5 & 6 & 0 & 0 \\
\hline Massachusetts & 5.95 & 5.95 & 100,000 & 100,000 \\
\hline Michigan & 4.6 & 4.4 & 3,500 & 3,500 \\
\hline Minnesota & 8 & 8.86 & No limit & 200,000 \\
\hline Mississippi & 4.75 & 4.85 & 30,000 & 75,000 \\
\hline Missouri & 4.39 & 6 & 8,000 & 8,000 \\
\hline Montana & 8.59 & 6.83 & 40,000 & 40,000 \\
\hline Nebraska & 6.4 & 7 & 10,000 & 10,000 \\
\hline Nevada & 0 & 0 & 90,000 & 125,000 \\
\hline New Hampshire & 0 & 0 & 5,000 & 30,000 \\
\hline New Jersey & 3.5 & 6.37 & 0 & 0 \\
\hline New Mexico & 7.83 & 8.4 & 20,000 & 30,000 \\
\hline New York & 7.88 & 6.85 & 10,000 & 10,000 \\
\hline North Carolina & 7 & 8.08 & 7,500 & 10,000 \\
\hline North Dakota & 3.77 & 5.25 & 80,000 & 80,000 \\
\hline Ohio & 6.9 & 7.2 & 5,000 & 5,000 \\
\hline Oklahoma & 6.72 & 6.05 & No limit & No limit \\
\hline Oregon & 8.12 & 9 & 15,000 & 25,000 \\
\hline Pennsylvania & 2.1 & 2.8 & 0 & 0 \\
\hline Rhode Island & 6.04 & 9.66 & 0 & 0 \\
\hline South Carolina & 7 & 7.3 & 5,000 & 5,000 \\
\hline South Dakota & 0 & 0 & No limit & No limit \\
\hline Tennessee & 0 & 0 & 5,000 & 5,000 \\
\hline Texas & 0 & 0 & No limit & No limit \\
\hline Utah & 6.26 & 5.72 & 8,000 & 8,000 \\
\hline Vermont & 6.54 & 8.85 & 30,000 & 30,000 \\
\hline Virginia & 5.75 & 5.75 & 5,000 & 5,000 \\
\hline Washington & 0 & 0 & 30,000 & 30,000 \\
\hline West Virginia & 6.5 & 6.5 & 7,500 & 15,000 \\
\hline Wisconsin & 6.93 & 6.93 & 40,000 & 40,000 \\
\hline Wyoming & 0 & 0 & 10,000 & 10,000 \\
\hline Federal & & & 7,500 & 15,000 \\
\hline
\end{tabular}


allows the federal option, the maximum of the state and federal exemption levels. If this is greater than the average house price in the state, we use the average house price instead, which is a more accurate representation of the exemption that the average person would get. We then multiply this by the state's homeownership rate and, if the state allows married householders to double the exemption, we also multiply it by 1 plus the state's share of households in which both spouses reside together. The result of this divided by the average house price yields our homestead exemption rate.

Note that the sources for all of the data used to construct our variables are given in the data appendix, as are the summary statistics for all of the independent variables described above. We should also note that our two most important independent variables - the homestead exemption rate and the maximum marginal tax rate-are uncorrelated, with a correlation coefficient of -0.01 .

As we mention above, one of the main benefits of our panel approach is that the relative abundance of observations means that we can easily allow for nonlinearities. This is important because, for each of our government policy variables, there are opposing effects, meaning that the relationships might be non-monotonic. This is easiest to see with tax rates, for which the standard negative labor-effort effect is countered by the positive taxevasion effect. Assuming a non-trivial cost to being caught evading taxes, at low tax rates the incentive to evade taxes will not be terribly strong because the net expected benefits are not very high. Conversely, under very high tax rates, the benefit of evading taxes is much higher.

In preliminary analyses, we found that a cubic specification fits the homestead exemption rate well, whereas a quadratic specification fits the tax variable well. Thus, our baseline model, which we report and discuss in detail below, uses a quadratic tax variable and a cubic homestead exemption variable. In the section following our discussion of the baseline results, we discuss alternative specifications, the final of which justifies the cubic specification for the homestead exemption rate.

\section{EMPIRICAL RESULTS}

Our dependent variable is the rate of entrepreneurship, as defined above, for 1991-98, and our independent variables are all lagged by one year. To allow for the most general error structure given our data constraints, we estimate (1) using feasible generalized least squares (FGLS). This allows for state-specific heteroskedastic errors, although, because of a relatively short panel, we still need to assume that errors are uncorrelated across states (Beck and Katz, 1995). We also allow for each state's errors to follow their own AR(1) process.

Table 2 summarizes our results. As discussed above, we attach little importance to the coefficients on our demographic and business conditions variables, but simply note that omitting them would have a statistically significant effect on the results. More importantly, our estimation indicated that the marginal tax rate and the homestead exemption rate are both related nonmonotonically to the rate of entrepreneurship.

Our estimates of the effects of marginal tax rates on entrepreneurship indicate that at tax rates at the low end of our observed rates-28 to 35 percent-an increase in the tax rate will reduce the number of entrepreneurs (see Figure 2). Beyond this range, higher marginal taxes will increase the number of entrepreneurs indirectly as, presumably, the tax-evasion incentives become large enough to begin outweighing the possible penalties.

The cubic relationship between the homestead exemption rate and entrepreneurship is illustrated by Figure 3. At very low and very high exemption rates-between 0 and 20 percent and above 60 percent-an increase in the homestead exemption leads to a decrease in the rate of entrepreneurship, suggesting that the credit-access effect dominates. At the mid-range of exemption rates-between 20 and 60 percent-an increase in the homestead exemption rate leads to an increase in the rate of entrepreneurship, suggesting that the wealthinsurance effect dominates. Note, though, that only rates between 50 and 72 percent lead to a higher rate of entrepreneurship than there would be with no homestead exemption at all.

The year dummies are also interesting and 
Table 2

Baseline FGLS Results

\begin{tabular}{|c|c|c|c|}
\hline \multicolumn{4}{|c|}{$\begin{array}{c}\text { Dependent variable: } \\
\text { state rate of entrepreneurship }=\text { (nonfarm proprietors' employment) } /(\text { working-age population })\end{array}$} \\
\hline & Coefficient & Standard error & t-Statistic \\
\hline \multicolumn{4}{|l|}{ Policies } \\
\hline Maximum marginal tax rate & -0.092 & 0.056 & -1.66 \\
\hline Maximum marginal tax rate squared & $1.3 \mathrm{e}^{-3}$ & $0.7 \mathrm{e}^{-3}$ & 1.75 \\
\hline Homestead exemption rate & -0.118 & 0.024 & -4.93 \\
\hline Homestead exemption rate squared & 0.004 & 0.001 & 4.77 \\
\hline Homestead exemption rate cubed & $-3.3 \mathrm{e}^{-5}$ & $0.7 \mathrm{e}^{-5}$ & -4.69 \\
\hline \multicolumn{4}{|l|}{ Demographics } \\
\hline Adult share aged 45-65 & 0.173 & 0.054 & 3.22 \\
\hline Adult share aged $65+$ & 0.034 & 0.078 & 0.44 \\
\hline Female share & 0.080 & 0.020 & 4.06 \\
\hline Black share & -0.146 & 0.086 & -1.70 \\
\hline Native American share & 0.175 & 0.407 & 0.43 \\
\hline Asian and Pacific Islander share & -0.111 & 0.180 & -0.62 \\
\hline Hispanic share & -0.067 & 0.066 & -1.01 \\
\hline \multicolumn{4}{|l|}{ Business conditions } \\
\hline Unemployment rate & 0.106 & 0.025 & 4.26 \\
\hline Real per capita income & $-1.1 e^{-4}$ & $0.9 \mathrm{e}^{-4}$ & -1.23 \\
\hline Real per capita wealth & 0.310 & 0.229 & 1.35 \\
\hline Relative proprietor's wage & 0.342 & 0.399 & 0.86 \\
\hline Industry shares & Yes & - & - \\
\hline \multicolumn{4}{|l|}{ Year dummies } \\
\hline 1992 & -0.221 & 0.055 & -4.01 \\
\hline 1993 & -0.106 & 0.090 & -1.18 \\
\hline 1994 & 0.207 & 0.119 & 1.73 \\
\hline 1995 & 0.606 & 0.152 & 3.98 \\
\hline 1996 & 1.038 & 0.183 & 5.67 \\
\hline 1997 & 1.153 & 0.219 & 5.25 \\
\hline 1998 & 1.224 & 0.255 & 4.81 \\
\hline State fixed effects & Yes & - & - \\
\hline Constant & -22.442 & 119.659 & -0.19 \\
\hline
\end{tabular}

Log-likelihood

Number of observations

400

Estimated covariances

50

Estimated autocorrelations

50

NOTE: The estimation corrects for state-specific heteroskedasticity and autocorrelation. Omitted reference variables are as follows: adult share aged 18-44, white share of employment, government share of employment, and 1991. 
Figure 2

\section{Entrepreneurship and Marginal Taxes}

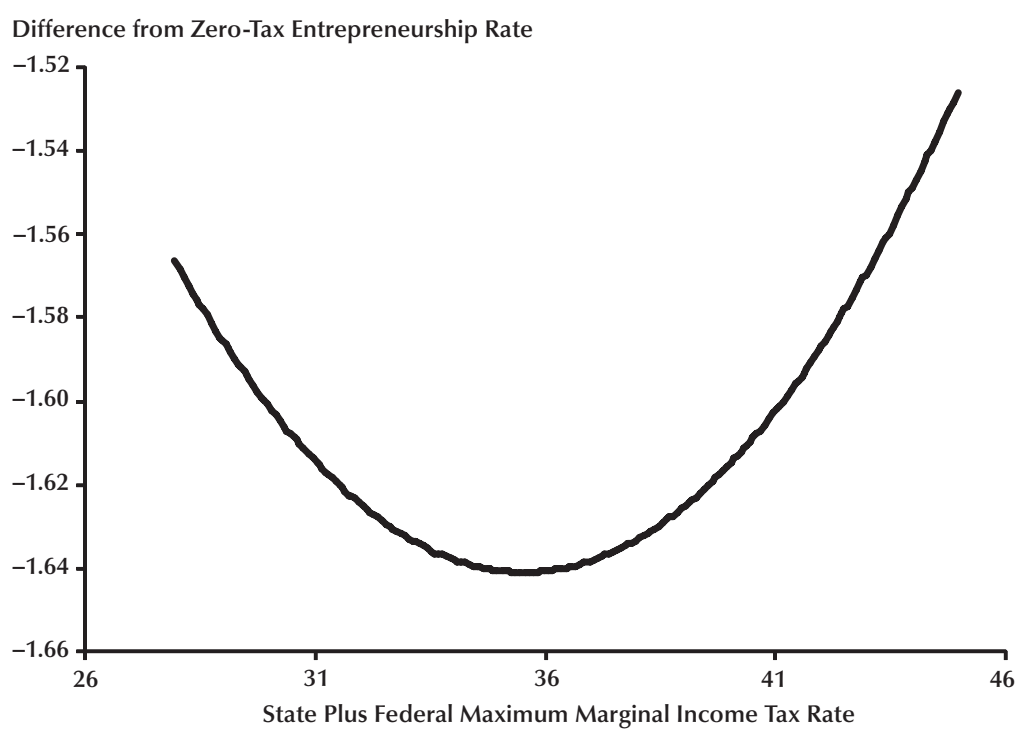

\section{Figure 3}

\section{Entrepreneurship and the Homestead Exemption}

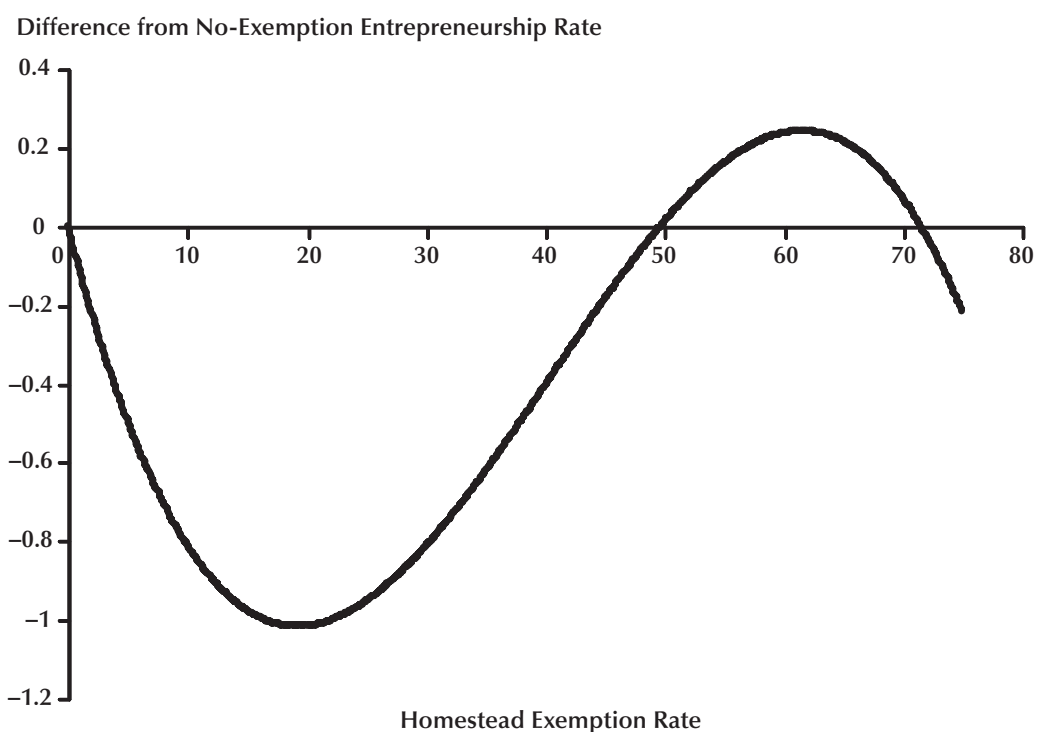




\section{Figure 4}

\section{Estimated State Fixed Effects}

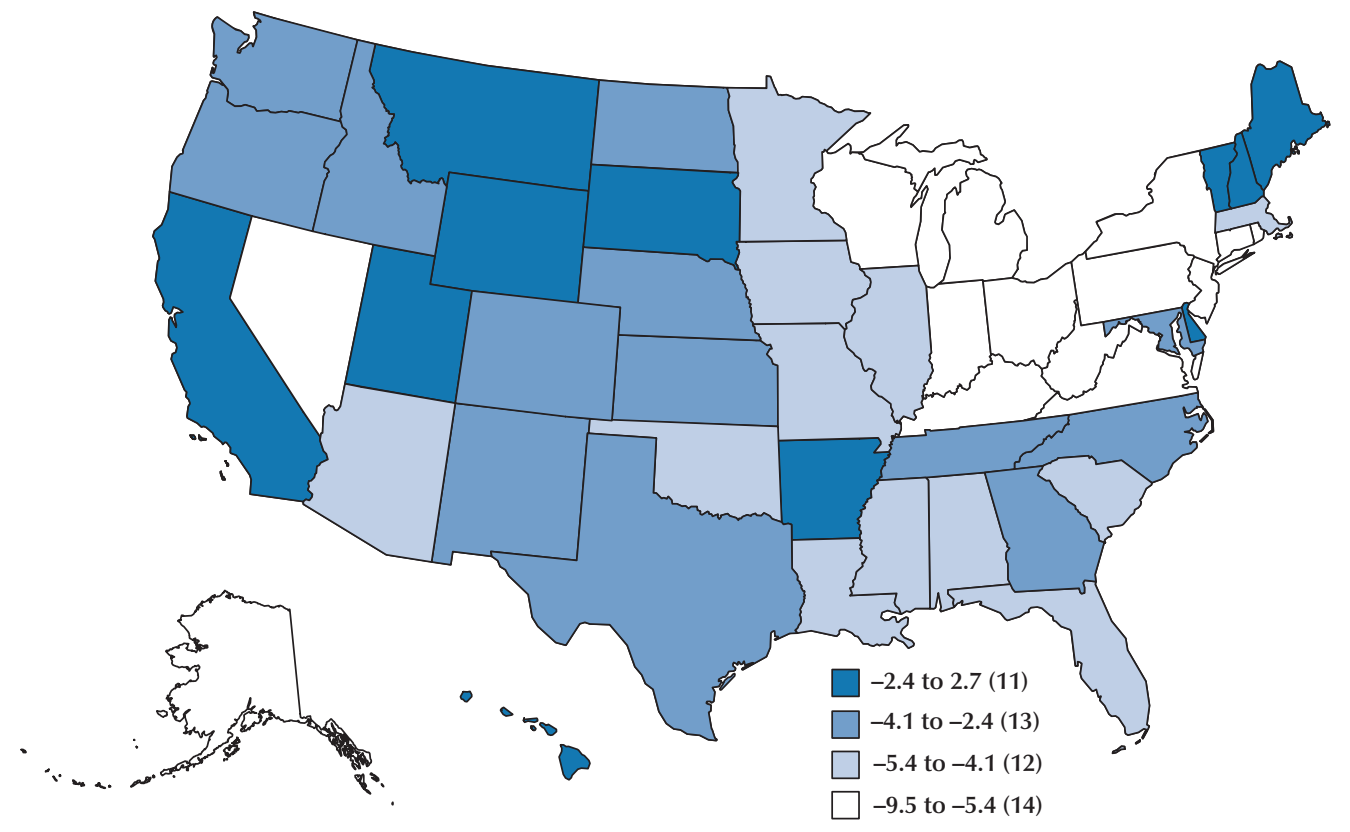

suggest an underlying trend in entrepreneurship not captured by demographics, business conditions, or government policies. The estimated coefficient on the 1998 dummy indicates that state rates of entrepreneurship would have risen, on average, by 1.2 percentage points from 1991 to 1998 had all of the variables we include in our estimation remained at their initial levels.

Figure 4 plots the estimated fixed effects across the states, illustrating the extent to which differences in entrepreneurship are determined by differences in the variables included in our regression. Most noticeably, comparing Figures $1 \mathrm{~A}$ and 4 , we see that not all states with low levels of entrepreneurship also have low estimated fixed effects. In particular, states in the Great Lakes, Upper South, and Deep South regions have low levels of entrepreneurship, typically falling in the lowest quartile. However, the fixed effects for the Deep South states are not in the lowest quartile, while those for the Great Lakes and Upper South states are. This indicates that the relatively low levels of entrepreneurship in the Deep South are due to relatively inhospitable business conditions, demographic factors, or government policies. On the other hand, the low levels of entrepreneurship in the Great Lakes and Upper South are attributable to fixed factors, which Georgellis and Wall (2000a) suggest might include cultural, historical, or sociological factors that suppress entrepreneurship. At the other extreme are states in New England and the West, which have high levels of entrepreneurship and high estimated fixed effects. These conditions suggest that one of the reasons for the high levels of entrepreneurship is that these states contain the cultural, historical, and sociological makeup to pursue and succeed in entrepreneurship.

\section{ALTERNATIVE ESTIMATES}

Our baseline model uses specific functional forms for the policy variables and generalized least-squares estimation to allow for state-specific autocorrelation and cross-sectionally uncorrelated 


\section{Table 3}

\section{Alternative FGLS Results}

Dependent variable: state rate of entrepreneurship $=$ (nonfarm proprietors' employment)/(working-age population)

\begin{tabular}{|c|c|c|c|c|c|c|}
\hline & $\mathbf{I}$ & II & III & IV & $\mathbf{V}$ & VI \\
\hline Maximum marginal tax rate & $\begin{array}{c}0.008^{*} \\
(0.004)\end{array}$ & $\begin{array}{c}-0.096^{*} \\
(0.055)\end{array}$ & $\begin{array}{c}0.066 \\
(0.084)\end{array}$ & $\begin{array}{c}-0.134^{*} \\
(0.065)\end{array}$ & $\begin{array}{c}-0.129 * \\
(0.065)\end{array}$ & $\begin{array}{r}-0.119 * \\
(0.053)\end{array}$ \\
\hline Maximum marginal tax rate squared & - & $\begin{array}{c}1.4 \mathrm{e}^{-3 *} \\
\left(0.7 \mathrm{e}^{-3}\right)\end{array}$ & $\begin{array}{c}0.001 \\
(0.001)\end{array}$ & $\begin{array}{c}0.002^{*} \\
(0.001)\end{array}$ & $\begin{array}{c}0.002^{*} \\
(0.001)\end{array}$ & $\begin{array}{c}0.002^{*} \\
(0.001)\end{array}$ \\
\hline Homestead exemption rate & $\begin{array}{c}-0.003 \\
(0.004)\end{array}$ & $\begin{array}{c}-0.010 \\
(0.009)\end{array}$ & $\begin{array}{c}-0.158^{*} \\
(0.029)\end{array}$ & $\begin{array}{c}-0.116^{*} \\
(0.023)\end{array}$ & $\begin{array}{c}-0.115^{*} \\
(0.023)\end{array}$ & - \\
\hline Homestead exemption rate squared & - & $\begin{array}{c}9.8 \mathrm{e}^{-5} \\
\left(9.9 \mathrm{e}^{-5}\right)\end{array}$ & $\begin{array}{c}0.006^{*} \\
(0.001)\end{array}$ & $\begin{array}{c}0.004^{*} \\
(0.001)\end{array}$ & $\begin{array}{c}0.004^{*} \\
(0.001)\end{array}$ & - \\
\hline Homestead exemption rate cubed & - & - & $\begin{array}{c}-4.9 \mathrm{e}^{-5 *} \\
\left(0.9 \mathrm{e}^{-5}\right)\end{array}$ & $\begin{array}{c}-3.2 \mathrm{e}^{-5 *} \\
\left(0.7 \mathrm{e}^{-5}\right)\end{array}$ & $\begin{array}{c}-3.2 \mathrm{e}^{-5 *} \\
\left(0.7 \mathrm{e}^{-5}\right)\end{array}$ & - \\
\hline Second octile of homestead exemption rate & - & - & - & - & - & $\begin{array}{c}-0.285^{*} \\
(0.087)\end{array}$ \\
\hline Third octile of homestead exemption rate & - & - & - & - & - & $\begin{array}{r}-0.391 * \\
(0.095)\end{array}$ \\
\hline Fourth octile of homestead exemption rate & - & - & - & - & - & $\begin{array}{c}-0.477^{*} \\
(0.199)\end{array}$ \\
\hline Fifth octile of homestead exemption rate & - & - & - & - & - & $\begin{array}{r}-0.445^{*} \\
(0.126)\end{array}$ \\
\hline Sixth octile of homestead exemption rate & - & - & - & - & - & $\begin{array}{c}0.146 \\
(0.165)\end{array}$ \\
\hline Seventh octile of homestead exemption rate & - & - & - & - & - & $\begin{array}{c}0.382^{*} \\
(0.233)\end{array}$ \\
\hline Eighth octile of homestead exemption rate & - & - & - & - & - & $\begin{array}{c}0.259 * \\
(0.232)\end{array}$ \\
\hline $\begin{array}{l}\text { Demographics, business conditions, } \\
\text { year and state effects }\end{array}$ & Yes & Yes & Yes & Yes & Yes & Yes \\
\hline Heteroskedasticity & Yes & Yes & No & Yes & Yes & Yes \\
\hline Autocorrelation & State & State & State & None & Common & State \\
\hline Log-likelihood & -7.56 & -4.49 & -114.92 & -26.55 & -26.46 & 0.514 \\
\hline
\end{tabular}

NOTE: Standard errors are in parentheses; * indicates statistical significance at the 10 percent level. Alternative I: baseline model with restriction that higher-order effects of policy variables are zero.

Alternative II: baseline model with restriction that third-order effect of homestead exemption is zero. Alternative III: baseline model with assumption that errors are homoskedastic.

Alternative IV: baseline model with assumption that errors are not autocorrelated.

Alternative $\mathrm{V}$ : baseline model with assumption that autocorrelation is common across states.

Alternative VI: baseline model with home exemption rate octiles and state-specific heteroskedasticity and autocorrelation. 
heteroskedasticity. To check the consequence of these choices on our estimation of the effects of our policy variables, we present the results of six alternatives. ${ }^{8}$ These alternative results, which either use a different specification of the policy variables or place stronger restrictions on the error terms, are reported in Table 3 and illustrated by Figures 5 and 6.

Alternative I restricts the coefficients on the squared and cubed terms of the policy variables to zero. Estimation under these restrictions yields a positive and statistically significant effect for the marginal tax rate on entrepreneurship and a negative but statistically insignificant effect for the homestead exemption rate. Alternative II restricts the coefficient on the cubed term of the homestead exemption rate to zero while using the same quadratic functional form for the marginal tax rate as in the baseline model. The estimated relationship between the maximum marginal tax rate and entrepreneurship under this restriction differs very little from the baseline results. On the other hand, as previously stated, the estimated coefficients on the homestead exemption rate are both statistically no different from zero. The results from these two alternative specifications indicate that the choices we have made about the specification of the policy variables are important for our conclusions. Likelihood ratio tests reject the null hypotheses that the restrictions that these alternatives place on the higher-order terms do not have a statistically significant effect on the estimation. Therefore, the least-restrictive baseline model is preferred statistically to the two alternatives.

Three other alternatives place stronger restrictions on the error terms than does the baseline model: In alternative III they are assumed to be homoskedastic, in alternative IV they are not autocorrelated, and in alternative $\mathrm{V}$ their autocorrelation is common across states. As Figure 5 illustrates, none of these restrictions has an effect on the estimated U-shape for the relationship between marginal tax rates and the rate of entrepreneurship, although the coefficients in alter-

8 Wall (2004) demonstrates how not allowing for autocorrelation and heteroskedasticity, in particular, has severe consequences for the state-level panel of entrepreneurship in Black and Strahan (2002). native III are not statistically significant. The important differences are that the estimated relationship is flatter with alternative III and steeper with alternatives IV and V.

For the relationship between the homestead exemption rate and the rate of entrepreneurship, only the estimates from alternative III differ in any non-trivial way. All three alternatives yield an S-shaped relationship, although the estimated relationship is everywhere steeper with alternative III than with the baseline model. Another important difference is that alternative III suggests that all homestead exemption rates above 42 percent will yield more entrepreneurship than would a zero exemption, whereas the baseline model suggests that this is true only for homestead exemption rates between 50 and 72 percent.

Alternative VI replaces the continuous homestead exemption variables with dummy variables for discrete ranges of the homestead exemption rate. Because this model removes any general assumption regarding functional form, it allows us to verify the general shape of the cubic relationship of our baseline model. We split the observed homestead exemption rates into octiles, each with 50 observations, and estimate the model with the first octile omitted to avoid perfect collinearity. As summarized by Table 3, for all but one of the octiles of the homestead exemption rate, the rate of entrepreneurship is statistically different from what it would be under the first octile. Further, as illustrated by Figure 6, these results confirm the general S-shape to the relationship between the homestead exemption rate and the rate of entrepreneurship. Note also that this specification has little effect on the estimated relationship between the rate of entrepreneurship and the maximum marginal tax rate.

\section{CONCLUDING REMARKS}

This paper uses the panel approach of Georgellis and Wall (2000a) to estimate the effects of personal income tax rates and bankruptcy exemptions on entrepreneurship. Using data for all 50 states of the United States for 1991-98, we find non-monotonic relationships. Specifically, at low initial tax levels, an increase in marginal 
Figure 5

Alternative Estimates: Maximum Marginal Tax Rate
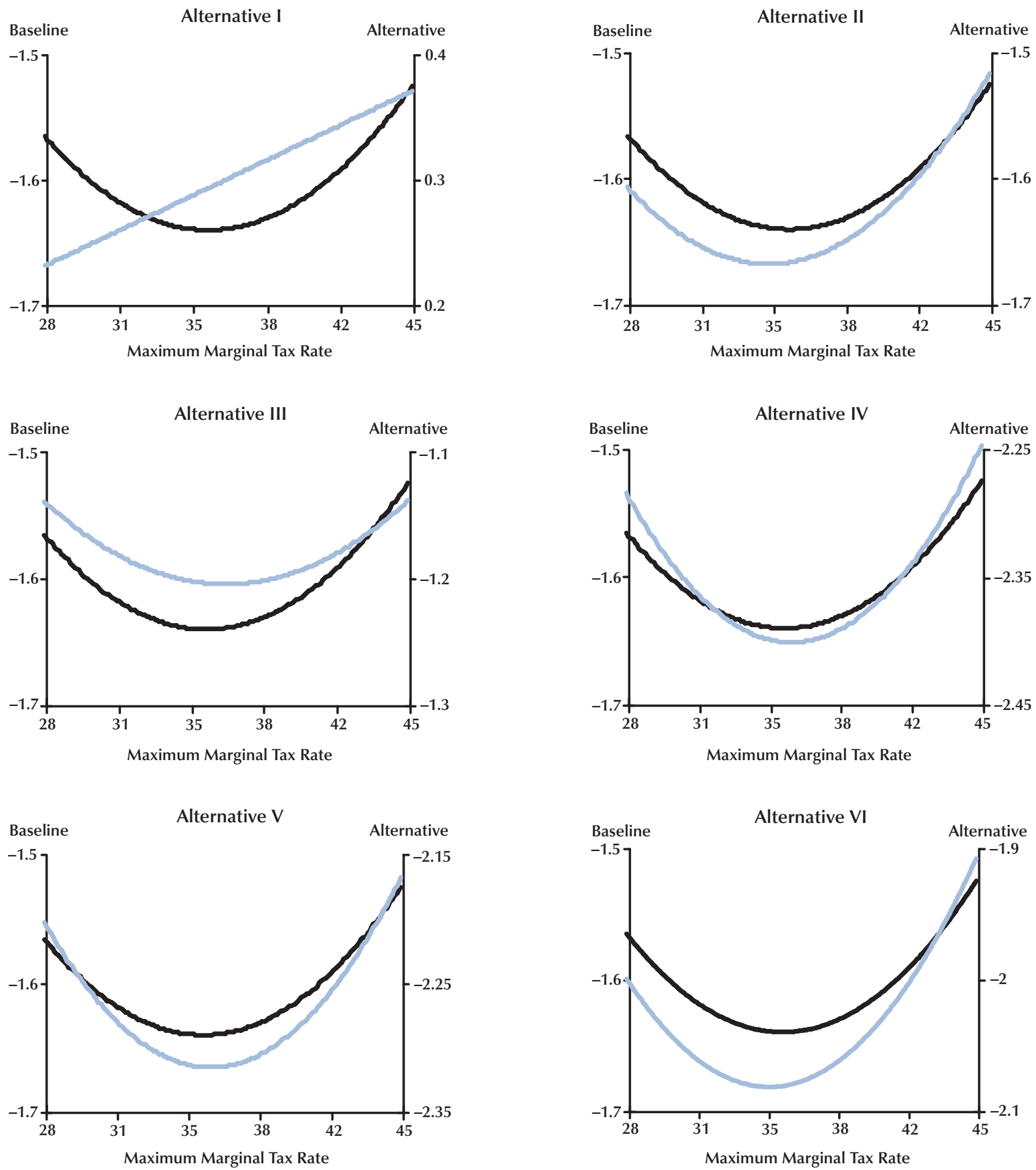

NOTE: Alternative I: baseline model with restriction that higher-order effects of policy variables are zero; Alternative II: baseline model with restriction that third-order effect of homestead exemption is zero; Alternative III: baseline model with assumption that errors are homoskedastic; Alternative IV: baseline model with assumption that errors are not autocorrelated; Alternative V: baseline model with assumption that autocorrelation is common across states; Alternative VI: baseline model with home exemption rate octiles and state-specific heteroskedasticity and autocorrelation. 
Figure 6

Alternative Estimates: Homestead Exemption Rate

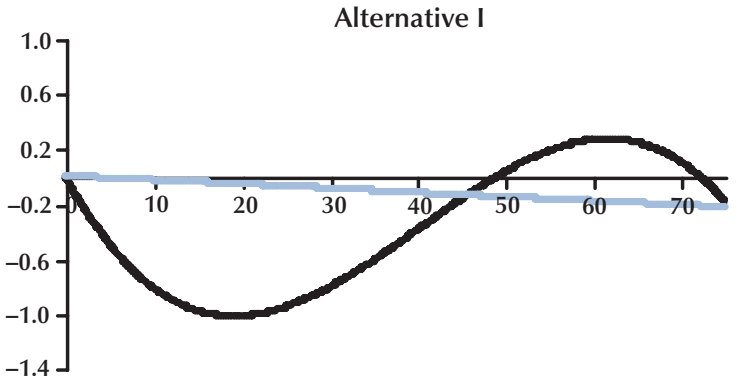

Homestead Exemption Rate

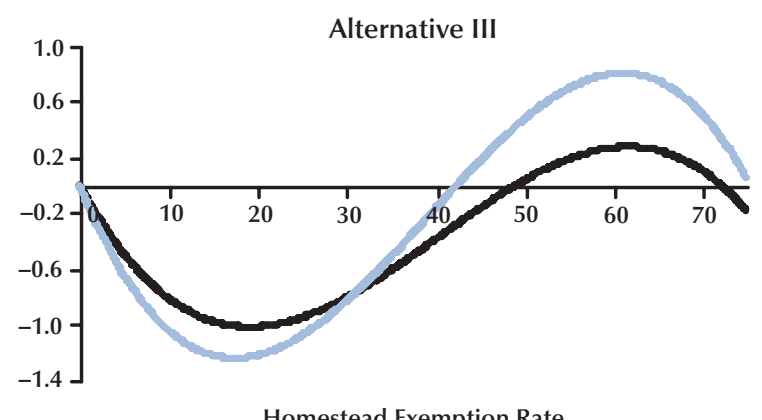

Homestead Exemption Rate

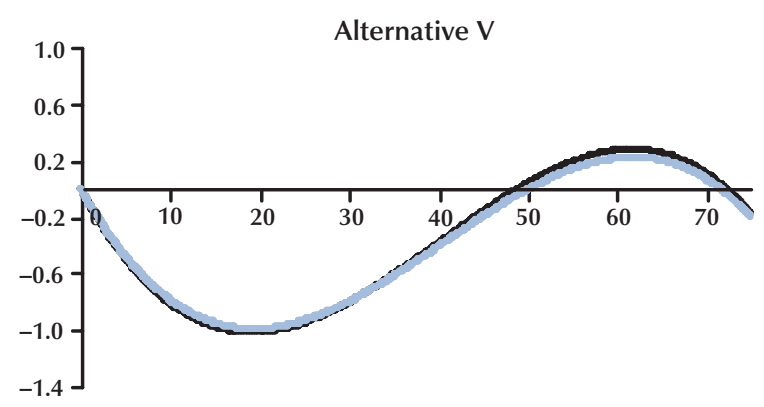

Homestead Exemption Rate

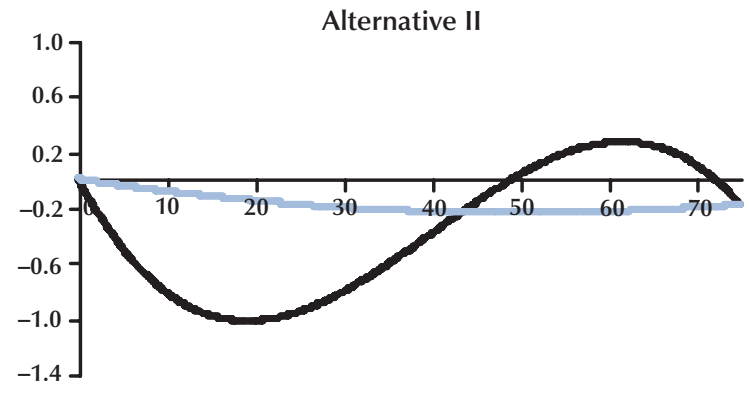

Homestead Exemption Rate

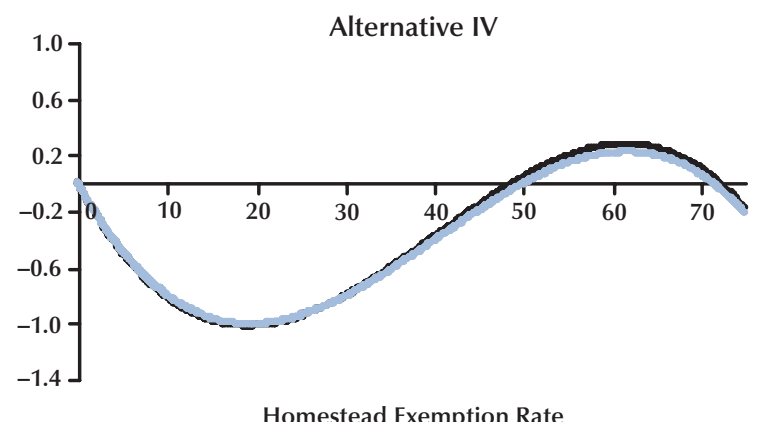

Homestead Exemption Rate

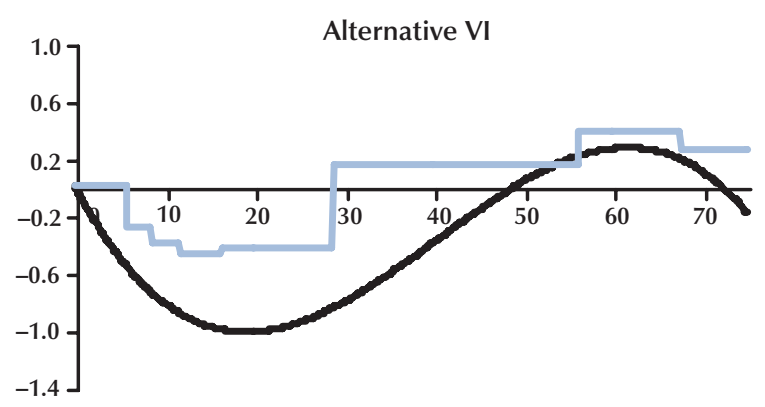

Homestead Exemption Rate

NOTE: Alternative I: baseline model with restriction that higher-order effects of policy variables are zero; Alternative II: baseline model with restriction that third-order effect of homestead exemption is zero; Alternative III: baseline model with assumption that errors are homoskedastic; Alternative IV: baseline model with assumption that errors are not autocorrelated; Alternative V: baseline model with assumption that autocorrelation is common across states; Alternative VI: baseline model with home exemption rate octiles and state-specific heteroskedasticity and autocorrelation. 
tax rates reduces the number of entrepreneurs, although at higher initial tax levels it will do the opposite. We also find that at very low and very high initial levels, an increase in the homestead exemption will reduce the number of entrepreneurs. In the mid-range of homestead exemption rates, there is a positive relationship between the exemption level and entrepreneurship. Further, only for relatively high homestead exemption rates will the level of entrepreneurship be higher than if there were no homestead exemption at all.

\section{REFERENCES}

Beck, Nathaniel and Katz, Jonathan N. "What to Do (and Not To Do) with Time-Series Cross-Section Data." American Political Science Review, September 1995, 89(3), pp. 634-47.

Berkowitz, Jeremy and White, Michelle J. "Bankruptcy and Small Firms' Access to Credit." RAND Journal of Economics, Spring 2004, 35(1), pp. 69-84.

Black, Sandra E. and Strahan, Philip E. "Entrepreneurship and Bank Credit Availability." Journal of Finance, December 2002, 57(6), pp. 2807-33.

Blanchflower, David G. "Self-Employment in OECD Countries." Labour Economics, September 2000, 7(5), pp. 471-505.

Blanchflower, David G. and Oswald, Andrew J. "What Makes an Entrepreneur?" Journal of Labor Economics, January 1998, 16(1), pp. 26-60.

Blau, David M. "A Time-Series Analysis of SelfEmployment in the United States." Journal of Political Economy, June 1987, 95(3), pp. 445-67.

Bruce, Donald. "Effects of the United States Tax System on Transitions into Self-Employment." Labour Economics, September 2000, 7(5), pp. 545-74.

Bruce, Donald J.; Deskins, John and Mohsin, Mohammed. "State Tax Policies and Entrepreneurial Activity: A Panel Data Analysis." National Tax Association, Proceedings of the 96th Annual Conference on Taxation, 2004.
Bruce, Donald and Holtz-Eakin, Douglas. "Who Are the Entrepreneurs? Evidence from Taxpayer Data." Journal of Entrepreneurial Finance and Business Ventures, 2001, 1(1), pp. 1-10.

Bruce, Donald and Mohsin, Mohammed. "Tax Policy and Entrepreneurship: New Time Series Evidence." Working paper, University of Tennessee-Knoxville, 2003 (forthcoming in Small Business Economics).

Cowling, Marc and Mitchell, Peter. "The Evolution of U.K. Self-Employment: A Study of Government Policy and the Role of the Macroeconomy." The Manchester School of Economic and Social Studies, September 1997, 65(4), pp. 427-42.

Cullen, Julie Berry and Gordon, Roger H. "Taxes and Entrepreneurial Activity: Theory and Evidence for the U.S." NBER Working Paper 9015, National Bureau of Economic Research, June 2002.

Dunn, Thomas and Holtz-Eakin, Douglas. "Financial Capital, Human Capital, and the Transition to SelfEmployment: Evidence from Intergenerational Links." Journal of Labor Economics, April 2000, 18(2), pp. 282-305.

Dye, Ronald A. "An Economic Analysis of Bankruptcy Statutes.” Economic Inquiry, July 1986, 24(3), pp. 417-28.

Evans, David S. and Jovanovic, Boyan. "An Estimated Model of Entrepreneurial Choice under Liquidity Constraints." Journal of Political Economy, August 1989, 97(4), pp. 808-27.

Evans, David S. and Leighton, Linda S. "Some Empirical Aspects of Entrepreneurship.” American Economic Review, June 1989, 79(3), pp. 519-35.

Fan, Wei and White, Michelle J. "Personal Bankruptcy and the Level of Entrepreneurial Activity." Journal of Law and Economics, October 2003, 46(2), pp. 543-67.

Fay, Scott; Hurst, Erik and White, Michelle J. "The Household Bankruptcy Decision." American Economic Review, June 2002, 92(3), pp. 706-18.

Gentry, William M. and Hubbard, R. Glenn. “Tax 


\section{Georgellis and Wall}

Policy and Entrepreneurial Entry." American

Economic Review, May 2000, 90(2), pp. 283-87.

Georgellis, Yannis and Wall, Howard J. "What Makes a Region Entrepreneurial? Evidence from Britain." Annals of Regional Science, August 2000a, 34(3), pp. 385-403.

Georgellis, Yannis and Wall, Howard J. "Who Are the Self-Employed?” Federal Reserve Bank of St. Louis Review, November/December 2000b, 82(6), pp. 15-23.

Gill, Andrew M. "Choice of Employment Status and the Wages of Employees and the Self-Employed: Some Further Evidence." Journal of Applied Econometrics, July 1988, 3(3), pp. 229-34.

Gropp, Reint; Scholz, John Karl and White, Michelle J. "Personal Bankruptcy and Credit Supply and Demand." Quarterly Journal of Economics, February 1997, 112(1), pp. 217-51.

Hamilton, Barton H. "Does Entrepreneurship Pay? An Empirical Analysis of the Returns to SelfEmployment." Journal of Political Economy, June 2000, 108(3), pp. 604-31.

Holtz-Eakin, Douglas; Joulfaian, David and Rosen, Harvey S. "Entrepreneurial Decisions and Liquidity Constraints." RAND Journal of Economics, Summer 1994a, 25(2), pp. 334-47.

Holtz-Eakin, Douglas; Joulfaian, David and Rosen, Harvey S. "Sticking it Out: Entrepreneurial Survival and Liquidity Constraints." Journal of Political Economy, February 1994b, 102(1), pp. 53-75.

Hout, Michael and Rosen, Harvey. "Self-Employment, Family Background, and Race." Journal of Human Resources, Fall 2000, 35(4), pp. 670-92.

Le, Anh T. "Empirical Studies of Self-Employment." Journal of Economic Surveys, September 1999, 13(4), pp. 381-416.

Long, James E. "Income Taxation and the Allocation of Market Labor." Journal of Labor Research, Summer 1982a, 3(3), pp. 259-76.
Long, James E. "The Income Tax and SelfEmployment." National Tax Journal, March 1982b, 35(1), pp. 31-42.

Parker, Simon C. "A Time Series Model of SelfEmployment under Uncertainty." Economica, August 1996, 63(251), pp. 459-75.

Rees, Hedley and Shah, Anup. "An Empirical Analysis of Self-Employment in the U.K." Journal of Applied Econometrics, January 1986, 1(1), pp. 95-108.

Robson, Martin T. "The Rise in Self-Employment amongst UK Males.” Small Business Economics, May 1998, 10(3), pp. 199-212.

Robson, Martin T. and Wren, Colin. "Marginal and Average Tax Rates and the Incentive for SelfEmployment." Southern Economic Journal, April 1999, 65(4), pp. 757-73.

Schuetze, Herb J. “Taxes, Economic Conditions and Recent Trends in Male Self-Employment: A CanadaUS Comparison.” Labour Economics, September 2000, 7(5), pp. 507-44.

Taylor, Mark P. "Earnings, Independence or Unemployment: Why Become Self-Employed?" Oxford Bulletin of Economics and Statistics, May 1996, 58(2), pp. 253-66.

Wall, Howard J. "Entrepreneurship and the Deregulation of Banking." Economics Letters, March 2004, 82(3), pp. 333-39.

White, Michelle J. "Why It Pays to File for Bankruptcy: A Critical Look at Incentives under U.S. Bankruptcy Laws and a Proposal for Change." University of Chicago Law Review, Summer 1998, 65(3), pp. 685-732.

White, Michelle J. "Bankruptcy and Small Business." Regulation, Summer 2001, 24(2), pp. 18-20. 


\section{DATA APPENDIX}

\begin{tabular}{|c|c|}
\hline Data series & Source \\
\hline Nonfarm proprietors' employment & $\begin{array}{l}\text { Regional Economic Information System, Bureau of Economic } \\
\text { Analysis, Table CA25 }\end{array}$ \\
\hline Unemployment rate & Bureau of Labor Statistics \\
\hline Dividends, interest, and rent & $\begin{array}{l}\text { Regional Economic Information System, Bureau of Economic } \\
\text { Analysis, Table CA05 }\end{array}$ \\
\hline Per capita gross state product & Bureau of Economic Analysis \\
\hline $\begin{array}{l}\text { Average nonfarm proprietors' income; } \\
\text { average wage and salary disbursements }\end{array}$ & $\begin{array}{l}\text { Regional Economic Information System, Bureau of Economic } \\
\text { Analysis, Table CA30 }\end{array}$ \\
\hline Industry employment shares & Establishment Survey, Bureau of Labor Statistics \\
\hline Age, race, and sex employment shares & Bureau of Labor Statistics \\
\hline Maximum marginal tax rates & TAXSIM, National Bureau of Economic Research \\
\hline Homestead bankruptcy exemptions & $\begin{array}{l}\text { Elias, Renaur, and Leonard, How to File for Chapter } 11 \text { Bankruptcy, } \\
\text { various editions }\end{array}$ \\
\hline Median house price & $\begin{array}{l}\text { Derived using median house price from } 1990 \text { Census and the } \\
\text { Home Price Index from the Office of Federal Housing } \\
\text { Enterprise Oversight }\end{array}$ \\
\hline Home ownership rate & Bureau of the Census \\
\hline $\begin{array}{l}\text { Share of households with householder } \\
\text { and spouse }\end{array}$ & $\begin{array}{l}\text { Bureau of the Census, derived from } 1990 \text { and } 2000 \text { Census } \\
\text { assuming constant state-level rates of change }\end{array}$ \\
\hline
\end{tabular}

\section{Table A1}

\section{Summary Statistics}

\begin{tabular}{lcc} 
& Mean & Standard deviation \\
\hline Rate of entrepreneurship & 14.51 & 2.90 \\
Maximum marginal tax rate & 38.37 & 4.14 \\
Homestead exemption rate & 28.71 & 24.75 \\
Adult share aged 45-65 & 26.52 & 1.56 \\
Adult share aged 65+ & 17.12 & 2.56 \\
Female share of employment & 46.07 & 1.32 \\
Black share of employment & 9.90 & 9.34 \\
Native American share of employment & 1.66 & 2.94 \\
Asian and Pacific Islander share of employment & 3.11 & 8.73 \\
Hispanic share of employment & 5.91 & 7.87 \\
Unemployment rate & 5.72 & 1.49 \\
Real per capita income & $\$ 20,862$ & $\$ 3,746$ \\
Real per capita wealth & 4.08 & 0.83 \\
Relative proprietor's wage & 0.74 & 0.11 \\
\hline
\end{tabular}


